\title{
Jakarta Bay Reclamation : Political Interest and Ecological Crisis
}

\author{
Elok Faiqotul Mutia ${ }^{1}$, Herdis Herdiansyah ${ }^{2}$ \\ \{efmutia@gmail.com ${ }^{1}$, herdis@ui.ac.id $\left.{ }^{2}\right\}$
}

School of Environmental Science, Universitas Indonesia, Jl. Salemba Raya No. 4, Jakarta, Indonesia ${ }^{1}$, School of Environmental Science, Universitas Indonesia, Jl. Salemba Raya No. 4, Jakarta, Indonesia ${ }^{2}$

\begin{abstract}
Permit on Islet C and D has been issued and come up with new era of jakarta bay reclamation conflict. Conflicts that occur due to the construction of Jakarta bay reclamation are not new. The Jakarta Bay reclamation conflict has been going on for a long time. despite changing government, this conflict still occurs. The conflicts that occur are not only vertical conflicts between the government and the community and between the central government and the regions, but also horizontal conflicts between pro and contra communities, between institutions or ministries. This research is qualitative method with depth interview and literature review. The result of this research show that cause of conflict in Jakarta Bay Reclamation is political interest that also support by economical interest. The duration of this conflict shows that there are political and economic interests being sought. However, this interest actually forgets the purpose of development itself, namely welfare for the community. Seeing the impact of social change and economic losses that arise, it is necessary to look back on what interests are carried. In addition, good environmental management needs to be supported by strict policies and strict supervision.
\end{abstract}

Keywords: Conflict, Ecological Crisis, Jakarta Bay Reclamation, Political Interest.

\section{Introduction}

Jakarta new Governor, Anies Baswedan has issued permits (IMB) on Islet C and D, called Pantai Maju and Pantai Kita. It's come up with conflict that happened before. Conflicts that occur due to the construction of Jakarta bay reclamation are not new. In the 1980s, reclamation carried out in Muara Baru had received strong criticism from Emil Salim, as the first Minister of State for Development and Environmental Monitoring in Indonesia, because it was deemed not to meet the environmental permit requirements. Not only at the level of government agencies, this conflict also occurs because of business competition between developers. At this time, the rejection of farmers in the region also emerged.

In 2003, the issue of Jakarta Bay reclamation returned to concern after the Ministry of Environment and Forestry (KLHK) in the Jakarta Bay reclamation had been seen in 2003 by issuing a Decree of the Ministry of Environment No. 14 of 2003 concerning the Inability to Plan the North Coast Jakarta Reclamation and Revitalization Activities. This decree is based on a study that shows that reclamation increases the risk of flooding, especially in the northern region, damaging marine ecosystems, causing fishermen's income to decline, and disrupting the Muara Karang power plant. This decision was sued by 6 developers who carried out reclamation until the Supreme Court issued a decision to win a lawsuit for 6 developers in 2011. 
Permits issued during the government period, Fauzi Bowo and Basuki Tjahya Purnama, again raised strong opposition from the people who were members of the coalition to save the Jakarta bay. These permits were even sued because they were considered by the community to be of interest to the community by not doing socialization to the affected communities, especially the people who depend on Jakarta bay for their lives. In addition, the issuance of the permit was considered to be administrative and legal. Until then, the permit and rules for reclamation of the Jakarta bay are still one of the long debates.

The issue of Jakarta bay reclamation even became one of the issues that became the material for the Jakarta gubernatorial election campaign in 2017. Basuki Tjahya Purnama and Djarot Saiful Hidayat who agreed with the construction of the Jakarta bay reclamation. While his opponents, Anies Baswedan and Sandiaga Uno, refused the existence of the Jakarta bay relamasi. At the same time, this issue became very political when different statements emerged in several ministries. Different attitudes, even debating authority in implementation and supervision, make many of the assumptions that emerge mainly the issue of political interests.

Different political interests make the Jakarta bay reclamation conflict not have a meeting point to date. The lack of clarity in the policy on the certainty of whether or not the construction of the Jakarta bay reclamation will not only disturb developers who have already issued large investments, but also the people affected like fishermen. The total value of potential losses from jakarta bay reclamation is Rp. 207.153,292,610, - / year [1]. In addition, there are changes in social activities caused by the inability of the community to adapt [2]. Not only humans, but environmental conditions will certainly have an impact. However, policies that are not in the same direction, and are uncertain, make environmental management and the handling of environmental impacts not yet addressed. Neglecting the economic valuation of environmental impacts is also neglected. Even if the amount is calculated to reach 1.4 trillion rupiah [3]. It means, ecological crisis will threaten the sustainability of the environment around the bay of Jakarta.

Some studies on the reclamation policy in Indonesia also carry the concept of sustainability as an indicator of development. The research that assess the sustainable development of Makassar beach reclamation with the Reclamation Sustainable Index (RSI). RSI uses 9 indices from three indicators of environmental factors, namely coastal resources, buildings an $\mathrm{d}$ infrastructure [4]. The reclamation policy in Bali is considered not only damaging environmental sustainability but also causing social and cultural problems [5][6]. Although almost the same, this research will focus on the debate over the Jakarta bay reclamation policy. Does the policy not only pay attention to environmental sustainability, but also pay attention to social and economic issues.

\section{Methodology}


This research uses descriptive qualitative design that is to explain phenomena deductively and structurally which is the result of analysis of data and information obtained through in-depth interviews and discourse studies. In-depth interviews in this research used open-ended questions with interview guides attached in the appendix to this research. Discourse studies are the collection and search of data and information obtained through texts or documents such as official government press releases, news in print and online mass media, regulations or laws and articles. Informants in this study came from various sectors, from the central and regional governments, the coalition to save the Jakarta bay and also academics.

\section{Results and Discussion}

The government as the state organizer has authority in planning, implementing and supervising related to development involving national interests. This authority is reaffirmed in regulations either in the form of laws, regulations, decrees or other regulations. Jakarta Bay Reclamation which was formed through Presidential Decree No. 52 of 1995 concerning the Implementation of North Coast Jakarta Reclamation giving authority to the DKI Jakarta Provincial Government for planning, management and supervision. However, this authority must also coordinate with other institutions. For example, such as management rights (Hak Pengelolaan/HPL), the DKI Jakarta Provincial Government must obtain permission from the Ministry of Agrarian and Spatial Planning / Head of the National Land Agency. However, the issue of authority is overlapping when there are other regulations that also give authority "reclamation" to the Ministry of Maritime Affairs and Fisheries and also the Ministry of Transportation. This overlapping of authority will not be problematic if there are similarities in decisions, but in the case of the Jakarta Bay reclamation, this overlap in authority makes conflict.

If viewed from the regulatory side, the appointment of the Maritime Coordinating Minister is the coordinator of the Jakarta Bay reclamation joint committee which aims to resolve the conflict. So that the decision made or the cancellation of the Jakarta Bay reclamation should not be the authority of the Maritime Coordinating Ministry. Deeper, the results of in-depth interviews state that the results of the joint committee based on various studies conducted by committee members have been agreed. However, this agreement has never been an official decision because of the replacement of the Minister. The current status of the joint committee is only as a forum for coordination between institutions, but the final decision is in the hands of the Maritime Coordinating Ministry.

This shows that in a joint committee there is a power relation which is finally won by the interests of the group that wants reclamation to continue. Despite the regulation, the authority possessed by the Maritime Coordinating Ministry is not as strong as other institutions, but the existence of relations between actors who support the same interests makes the final decision in the hands of Minister Luhut Pandjaitan. Even though Rizal Ramli and Luhut institutionally have the same authority, the interests brought by Luhut Pandjaitan are stronger in relation. So, theoretically, there are several agreements even though there are also some differences in the concept of the authority of the Jakarta Bay reclamation.

Researchers agree with Afiff that changes in the environment, both in the context of the pollution that has occurred, efforts to improve or influence that will occur due to Jakarta Bay reclamation are the results of economic and political policies arising from the results of various actors in the context of a country and the interaction between countries, so that each actor cannot be seen as a monolithic and homogeneous group [7]. This means that struggles, resistance, and 
conflicts including cooperation and alliances can be found to arise between individuals or groups both in each category of actors and between actors. This is what makes the complexity of planning and management in government policies [8] which ultimately can cause or deteriorate environmental conditions in the Jakarta Bay.

Secondly, the researchers agreed with the concept of power which was shown by Facoult that the concept of power or authority does not apply if it is only seen as a matter given by the state, but power is network, spread everywhere, so that power can be found in all areas of human interaction [9]. This is evident from if we look at the Jakarta Bay reclamation problem, the same authority is given by the state to the Maritime Coordinating Ministry, but the relationship that Luhut Pandjaitan has has more economic power than Rizal Ramli, so the policy taken by Luhut Pandjaitan has more influence rather than Rizal Ramli.

Third, although Foucault agrees with power relations, there are some things that are slightly different, namely power is considered as an individual's freedom of action, and is not influenced by anything [10]. However, this researcher found that the actions of actors who gain power are not entirely free based on their will, but there is one thing that influences the interests. The researcher found that power relations are formed by the same interests. So that how the policymaking actors position their knowledge and authority to gain interests, then it will influence the existing policies in government institutions.

The conflict in the Jakarta Bay Reclamation arose because there were differences in attitudes that were pointed out by the Central Government and the Regional Government. This conflict is included in resource use conflicts which often occur due to conflicting values and interests [11] or in this case the values and interests are manifested in the form of attitudes. The attitude or response of an institution with one another that is not as good as it can lead to conflict [12], but this is worsened by the belief that with the knowledge that is owned by each party is correct and authorized.

In other side, the involvement of "economical interest" also show up with given access to the collaboration of public private partnership (PPP), the concept of cooperation between the government and the private sector in implementing project development, is included in the funding. The omission of developer access that is too free can be caused by the existence of power relations with decision-making actors. This proves that power relations can shape the ability of access in the utilization and mastery of natural resources or profitable material [13] which are carried out exploitatively for economic growth activities [14]. Policy uncertainty, tugging on moratorium actions, violations of environmental permits and building permits, indicate that there are or no rights that developers have, developers feel they have what is called Ribot and Peluso as "bundle of power" [15]. forming access to resources. Where these developers have bundles and networks (webs) of power that allow developers to do things they shouldn't do. The relationship between politicians, bureaucrats and entrepreneurs raises a chain of power relations and interests that are difficult to break, and if this is included in an environmental policy, the researchers agree with Saragih, will worsen the ecological conditions of the earth [26]. This is because the policy taken will only benefit actors in power relations that are usually related to political economic interests. It is evident from the results of the interviews and policy analysis which shows that to date the Jakarta Bay reclamation is still controlled by developers.

The conflict that occurs is also inseparable from who is the authorized actor in the institution. Douglas calls these actors stakeholders, where there are social relations that lead to conflict [17]. These actors play an important role in any available decision making. In the Jakarta Bay reclamation policy, we can see changes in actors influence changes in attitudes and policies 
and discourses that they form. This shows that in addition to seeing it as a conflict between institutions, this conflict also needs to be seen as a conflict between interested actors. Thus, research agrees with Bryant and Bailey that it is important to look at the role and influence of actors in conflict, because of the political interests and actions of actors who are political [18]. Each actor knows very well, knowledge of applicable regulations, overlapping authority, and also the effects of good or bad that can be generated. However, interest dominates the actor's attitude, which makes each actor position knowledge as desired in achieving his goals. Even than settling overlapping regulations and equating perceptions, often the actors involved in this conflict are looking for weaknesses in regulations, studies, and statements as a defense and blaming the conflicting parties.

\section{Conclusions}

The Jakarta Bay reclamation conflict has been going on for a long time. despite changing government, this conflict still occurs. The conflicts that occur are not only vertical conflicts between the government and the community and between the central government and the regions, but also horizontal conflicts between pro and contra communities, between institutions or ministries. The duration of this conflict shows that there are political and economic interests being sought. However, this interest actually forgets the purpose of development itself, namely welfare for the community. Seeing the impact of social change and economic losses that arise, it is necessary to look back on what interests are carried. In addition, good environmental management needs to be supported by strict policies and strict supervision.

Acknowledgments. This work is supported by Hibah PITTA 2018 funded by DRPM Universitas Indonesia No. 2579/UN.R3.1/HKP.05.00/2018

\section{References}

[1] Ramadhan, Andrian, Maulana Firdaus, Rizky Aprilian Wijaya, and Irwan Muliawan. : Economic Loss of Fisher and Fish Farmer Due to Reclamation of Jakarta Bay." Jurnal Sosial Ekonomi Kelautan dan Perikanan 11, no. 1 pp. 1-11 (2016)

[2] Hikmah, Hikmah, Armen Zulham, and Zahri Nasution. " Reclamation in The Jakarta Bay and Social Change of Fishing Community In the Cilincing of North Jakarta." Jurnal Kebijakan Sosial Ekonomi Kelautan dan Perikanan 8. No 1 pp. 1-12 (2018)

[3] Firdaus, Rendhy Farizy. "Estimasi biaya ekonomi proyek reklamasi pantai di Teluk Jakarta." (2017).

[4] Yurnita, A., Trisutomo, S., Ali, M.: Assessing the Sustainable Development of Coastal Reclamation: A Case of Makassar Using GIS Application. In IOP Conference Series: Earth and Environmental Science ,Vol. 79, No. 1, p. 012013. IOP Publishing (2017)

[5] Suryawan, N.: Marginalization Of Fishermen From Utilizing Coastal Area After Reclamation At Serangan Subdistrict, Denpasar, BalI. E-Journal of Cultural Studies, Vol 7, No. 1,pp. 1-12 (2014)

[6] Ardhana, I. P. G., Farhaeni, M.: The study of the impact for social culture toward the planning of reclamation for Benoa Bay in Bali. In AIP Conference Proceedings Vol. 1844, No. 1, p. 040001. AIP Publishing. (2017)

[7] Afiff, S. Pendekatan Ekologi Politik: Sebuah Pengantar. Tanah Air, pp. 18-33. (2009) 
[8] Walters, B. B., Rönnbäck, P., Kovacs, J. M., Crona, B., Hussain, S. A., Badola, R., DahdouhGuebas, F.: Ethnobiology, socio-economics and management of mangrove forests: a review. Aquatic Botany, Vol. 89, No. 2,pp. 220-236 (2008)

[9] Turama, A., R. :Pergeseran Kekuasaan Negara Dan Relasi Antarsubjek Dalam Cerpen Orde Baru Dan Reformasi." Jurnal Poetika 2.2 (2014).

[10] Foucault, M. : The archaeology of knowledge: Translated from the french by AM Sheridan Smith. Pantheon Books. (1972)

[11] Gray, B., Putnam, L. L. Means to what end? Conflict management frames. Environmental practice, Vol 5. No.3, pp. 239-246. (2003)

[12] Fisher, S. : Working with conflict: skills and strategies for action. Zed books(2000).

[13] Ribot, J. C., Peluso, N. L. : A theory of access. Rural sociology, Vol. 68, No. 2, pp. 153-181. (2003)

[14] Escobar, A.: Construction nature: Elements for a post-structuralist political ecology. Futures, Vol. 28, No. 4, pp. 325-343. (1996)

[15] Ribot, J. C., Peluso, N. L. : A theory of access. Rural sociology, Vol. 68, No. 2, pp. 153-181. (2003)

[16] Saragih, A. : Model Penanggulangan Bencana Di Kawasan Taman Nasional Gunung Leuser Dalam Persfektif Politik Ekologi. Politika: Jurnal Ilmu Politik, Vol. 7, No. 1, pp. 53-64. (2016).

[17] Douglas, J. A. : What's political ecology got to do with tourism?. Tourism Geographies, Vol 16, No. 1, pp. 8-13. (2014).

[18] Bryant, R. L., Bailey, S. : Third world political ecology. London: Routledge. (1997) 